\title{
A possible role of prostaglandin F-2 $\alpha$ in the development of ovarian follicles in guinea-pigs
}

\author{
W. H. Tam and R. J. J. Roy \\ Department of Zoology, University of Western Ontario, London, Ontario, Canada N6A 5B7
}

\begin{abstract}
Summary. Uterine PGF-2 $\alpha$ in the guinea-pig was eliminated by hysterectomy on Day 9 of the oestrous cycle and an increasing period of reduced PGF-2 $\alpha$ availability to the ovary was created by deferring replacement therapy with PGF- $2 \alpha$ from Day 9 to Day 11,13 and 15 . Ovulation, observed in $94 \%$ of the animals, was inevitably delayed. The treatment cycle length was progressively extended from the normal 15-16 days to 19-21 days. Similar results were obtained if endogenous PGF-2 $\alpha$ was suppressed by indomethacin injection instead of removing the uterus. That ovulation had been delayed and not occurred from more recently recruited follicles was evident from the total absence of atretic follicles of the expected size had they become atretic due to the lack of PGF-2 $\alpha$ at some critical time between Days 9 and 15. Pituitary homogenate and hCG injected on Day 16 shortened the PGF-2 $\alpha$ treatment cycle by 2 days, but stimulated ovulation in only $42 \%$ of the animals. When endogenous PGF- $2 \alpha$ was eliminated by hysterectomy and daily injections of indomethacin, follicular development ceased at approximately $0.8 \mathrm{~mm}$ instead of the $1.0 \mathrm{~mm}$ diameter found just before the preovulatory LH surge. It is suggested that (1) PGF- $2 \alpha$ has to act on developing follicles for a given period before they are capable of ovulation, and (2) that PGF- $2 \alpha$ is one of the factors required to stimulate the growth of the Graafian follicles at the end of the oestrous cycle.
\end{abstract}

\section{Introduction}

Current research on prostaglandins (PG) has led to the realization that these compounds fulfil many functions in reproductive processes. Evidence for the necessity of PGF-2 $\alpha$ to elicit the preovulatory LH surge is overwhelming (Sato, Taya, Jyujyo, Hirono \& Igarashi, 1974; Lau, Saksena \& Chang, 1974). Suggestions have also been made that PGs may be directly involved in some stages of ovarian follicular development, such as induction of meiotic division of oocytes (Tsafriri, Lindner, Zor \& Lamprecht, 1972a), preparation of the follicular wall (Strickland \& Beers, 1979) for eventual rupture (Tsafriri et al., 1972b), and enhancement of atresia (Tam, Beveridge \& Tso, 1982). The direct involvement of PGF- $2 \alpha$ in folliculogenesis is made more likely by the fact that in some species utero-ovarian venous blood concentrations of PGF-2 $\alpha$ rise well in advance of the preovulatory LH surge (Blatchley, Donovan, Horton \& Poyser, 1972; Thorburn, Cox, Currie, Restall \& Schneider, 1973; Croix \& Franchimont, 1975). The aim of the present study of hysterectomized guinea-pigs was to determine whether the inhibition of ovulation in such animals is due to the lack of gonadotrophins or PGF-2 $\alpha$ and which stage of follicular development is affected. 


\section{Materials and Methods}

Mature, virgin guinea-pigs, aged 2-4 months and weighing 450-800 g, were used. The management of animals, the calculation of oestrous cycle length and the method of hysterectomy were as described elsewhere (Tam et al., 1982). The animals were observed for 2 cycles and only those that had exhibited average normal cycle length (15-16 days) were used. The pre-experimental cycles were used as control cycles. PGF-2 $\alpha$ (Upjohn Co., Kalamazoo, Michigan, U.S.A.; 0.129 or $0.387 \mathrm{mg}$ of the free acid in $0.5 \mathrm{ml} 0.154 \mathrm{M}-\mathrm{NaCl}$, administered twice daily), indomethacin (Sigma Chemical Co., St Louis, Missouri, U.S.A.; 3.33 mg/100 g body weight/day in $0.5 \mathrm{ml}$ sesame oil), FSH (Sigma, contaminated with 0.3 Armour units of LH per Armour unit of FSH; 5 Armour units in $0.5 \mathrm{ml} 0.154 \mathrm{M}-\mathrm{NaCl}$ ) and hCG (Sigma; 10 i.u. in $0.5 \mathrm{ml} 0.154 \mathrm{M}-\mathrm{NaCl}$ ) were all given intraperitoneally. After the animals were killed with an overdose of diethyl ether, the ovaries were fixed in Bouin's fluid, embedded in paraffin wax, serially sectioned $(10 \mu \mathrm{m})$ and stained with haematoxylin and eosin. Follicular diameter was measured as described by Tso \& Tam (1977). Ovulation was established by the occurrence of vaginal membrane perforation, the presence of ovulation points and newly formed corpora lutea (CL) of ovulation in the ovary at autopsy. The number of ova ovulated was determined by the number of CL of ovulation in the ovarian sections. Results are presented as mean \pm s.e.m. (number of observations).

\section{Results}

\section{Experiment 1: effects of temporary lack of PGF-2 a on oestrous cycle length and ovulation}

The results are given in Table 1 . All the hysterectomized animals recovered uneventfully from surgery. Approximately one third of the animals gained about 5\% body weight and another third lost $5 \%$ body weight while the rest did not exhibit any noticeable weight changes when they were killed on Day 3 of the cycle following the treatment cycle. There was no consistent pattern between treatment cycle length and body weight change.

Table 1. Effects of hysterectomy (H, Day 9) or daily indomethacin injection (I, initiated on Day 9) and deferred PGF- $2 \alpha$ replacement therapy on ovulation in guinea-pigs

\begin{tabular}{|c|c|c|c|c|c|c|c|c|}
\hline \multirow[b]{3}{*}{ Group } & \multirow{3}{*}{$\begin{array}{l}\text { No. of } \\
\text { animals }\end{array}$} & \multirow{3}{*}{$\begin{array}{l}\text { Control cycle } \\
\text { (days) }\end{array}$} & \multicolumn{3}{|c|}{ Treatment } & \multicolumn{3}{|c|}{ Treatment cycle } \\
\hline & & & \multirow[b]{2}{*}{$\mathrm{H} / \mathrm{I}$} & \multicolumn{2}{|c|}{ PGF- $2 \alpha$} & \multirow{2}{*}{$\begin{array}{l}\text { Length } \\
\text { (days) }\end{array}$} & \multirow{2}{*}{$\begin{array}{c}\text { Duration of } \\
\text { PGF-2 } \alpha \text { before } \\
\text { ovulation (days) }\end{array}$} & \multirow{2}{*}{$\begin{array}{c}\text { No. of } \\
\text { ovulations }\end{array}$} \\
\hline & & & & from Day & $\mathrm{mg} / \mathrm{day}$ & & & \\
\hline $\mathbf{A}$ & 5 & $15.4 \pm 0.2$ & $\mathbf{H}$ & - & - & N.C. ${ }^{\dagger}$ & - & - \\
\hline B & 6 & $15 \cdot 3 \pm 0.3$ & $\mathrm{H}$ & 9 & 0.258 & $19.0 \pm 0.3$ & $11 \cdot 0 \pm 0.3$ & $3 \cdot 0 \pm 0 \cdot 3$ \\
\hline $\mathrm{C}$ & 6 & $16 \cdot 3 \pm 0.2$ & $\mathbf{H}$ & 11 & 0.258 & $19.7 \pm 1.0$ & $8.8 \pm 0.6 \ddagger$ & $2.8 \pm 0.5 \ddagger$ \\
\hline D & 6 & $15.8 \pm 0.3$ & $\mathbf{H}$ & 13 & 0.258 & $20.8 \pm 0.5$ & $9.0 \pm 0.5 \ddagger$ & $2.6 \pm 0.5 \ddagger$ \\
\hline $\mathrm{E}$ & 5 & $15.7 \pm 0.3$ & $\mathbf{H}$ & 15 & 0.258 & $21.4 \pm 0.5$ & $7.4 \pm 0.5$ & $2.2 \pm 0.4$ \\
\hline $\mathbf{F}$ & 5 & $15 \cdot 3 \pm 0.3$ & $\mathbf{H}$ & 11 & 0.774 & $22.6 \pm 2.4$ & $12.6 \pm 2.4$ & $3 \cdot 2 \pm 2 \cdot 4$ \\
\hline G & 5 & $15.5 \pm 0.2$ & I & - & - & N.C. $\dagger$ & - & - \\
\hline $\mathbf{H}$ & 5 & $15 \cdot 1 \pm 0 \cdot 1$ & I & 11 & 0.258 & $16.2 \pm 0.5$ & $6.2 \pm 0.5$ & $3.2 \pm 0.4$ \\
\hline I & 5 & $15.7 \pm 0.2$ & I & 13 & 0.258 & $17.2 \pm 0.5$ & $5 \cdot 2 \pm 0.5$ & $2.8 \pm 0.4$ \\
\hline $\mathrm{J}$ & 5 & $15.7 \pm 0.2$ & I & 15 & 0.258 & $18.2 \pm 0.9$ & $4.8 \pm 0.9 \ddagger$ & $2.8 \pm 0.5 \ddagger$ \\
\hline
\end{tabular}

* Intact guinea-pigs ovulate $2.8 \pm 0.2(n=18)$ follicles.

$\dagger$ N.C. $=$ cycle had not recurred when the animals were killed on Day 32. All other animals were killed on Day 3 of the cycle after the treatment cycle.

¥ In Groups $\mathbf{C}, \mathbf{D}$ and $\mathrm{J}$ one of the animals in each group did not ovulate and luteinized follicles with entrapped ova were found. These animals were not included in the calculations in the 2 right-hand columns. 
In each animal, the treatment cycle was significantly increased compared with the corresponding control cycles $(P<0.01$ or $<0.001, t$ test). The treatment cycle in hysterectomized animals was significantly longer $(P<0.02$ or $<0.001, t$ test $)$ than that for the corresponding indomethacin-injected animals. However, despite the longer period of reduced PGF- $2 \alpha$ availability to the ovary and even a 3-fold increase in the dose of PGF-2 $\alpha$ in Group F, there was no significant difference among the treatment cycle lengths within the hysterectomized or within the indomethacin-treated animals (ANOVA; $P<0.25$, for both). The duration of PGF-2 $\alpha$ treatment before the occurrence of ovulation in hysterectomized guinea-pigs was significantly longer than that for the corresponding groups treated with indomethacin $(P<0.02$ or $<0.001, t$ test). There was no significant difference in the duration of PGF- $2 \alpha$ treatment among Groups B, C, D and E (by ANOVA and the SNK a posteriori test or by Dunnett's test). Similarly, there was also no significant difference among Groups $\mathrm{H}, \mathrm{I}$ and J. Duration of PGF-2 $\alpha$ treatment in Group F was the longest because one animal in this group had a 31-day and another a 25-day treatment cycle. The number of ova ovulated appeared to be comparable with that for normal guinea-pigs. When serial sections of the ovaries were examined, no antral follicles approaching $0.8 \mathrm{~mm}$ diameter were found in 26 out of the 28 hysterectomized animals, a condition similar to that found in Day 3 intact guinea-pigs. Of the 2 animals that did not ovulate, both had healthy follicles of $0.8 \mathrm{~mm}$ diameter.

To confirm that the extension of the treatment cycle was due to delayed ovulation and not because of atresia of the follicles that were expected to ovulate on Day 15 or 16, 7 guinea-pigs receiving the same treatment as those in Groups D and E were killed 1-2 days before the expected day of ovulation (Day 20). The ovarian histology showed that every guinea-pig had 2-4 large antral follicles $>0.8 \mathrm{~mm}$, in diameter, and all these follicles were healthy.

Experiment 2: effects of gonadotrophins on ovulation in hysterectomized and PGF-2a or saline-treated animals

The results are presented in Tables 2 and 3. Vaginal perforation did not recur up to Day 32 of the treatment cycle in hysterectomized guinea-pigs treated with gonadotrophins alone (Groups A, C and E, Table 2). Their CL, many still with diameters of 1-2 mm, were all degenerate with highly vacuolated luteal cells and crenated nuclei. No entrapped ova were evident. Although there is a trend that the total number of CL present in each animal in Groups

Table 2. Effects of hysterectomy (Day 9), saline ( $9 \mathrm{~g} \mathrm{NaCl} / \mathrm{l}$ ) or PGF-2 $\alpha$ (from Day 13) and pituitary homogenate or gonadotrophin (Day 16) injections on oestrous cycle length and ovulation in guinea-pigs

\begin{tabular}{|c|c|c|c|c|c|c|c|}
\hline \multirow[b]{3}{*}{ Group } & \multirow[b]{3}{*}{$\begin{array}{l}\text { Treatment after } \\
\text { hysterectomy }\end{array}$} & \multirow[b]{3}{*}{$\begin{array}{l}\text { No. of } \\
\text { animals }\end{array}$} & \multirow[b]{3}{*}{$\begin{array}{l}\text { Control cycle } \\
\text { (days) }\end{array}$} & \multicolumn{4}{|c|}{ Treatment cycle } \\
\hline & & & & \multirow[b]{2}{*}{$\begin{array}{l}\text { Length } \\
\text { (days) }\end{array}$} & \multicolumn{2}{|c|}{ CL of ovulation } & \multirow[b]{2}{*}{$\begin{array}{l}\text { Total CL } \\
\text { per animal }\end{array}$} \\
\hline & & & & & $\begin{array}{l}\text { No. of } \\
\text { animals }\end{array}$ & $\begin{array}{l}\text { Diam. } \\
(\mathrm{mm})\end{array}$ & \\
\hline $\mathbf{A}$ & $\begin{array}{l}\text { Saline + pituitary } \\
\text { homogenate }\end{array}$ & 4 & $15 \cdot 2 \pm 0 \cdot 4$ & 一 & 0 & - & $6 \cdot 0 \pm 1 \cdot 2$ \\
\hline B & $\begin{array}{l}\text { PGF- } 2 \alpha+\text { pituitary } \\
\text { homogenate } \dagger\end{array}$ & 6 & $15 \cdot 9 \pm 0 \cdot 3$ & $18 \cdot 3 \pm 0 \cdot 5$ & 2 & $0.866 \pm 0.092$ & $6.0 \pm 0.9$ \\
\hline $\mathrm{C}$ & Saline + hCG & 4 & $15 \cdot 1 \pm 0.3$ & - & 0 & - & $4 \cdot 5 \pm 0.5$ \\
\hline D & PGF- $2 \alpha+$ hCG + & 6 & $15.4 \pm 0.3$ & $19.0 \pm 0.8$ & 3 & $1.169 \pm 0.192(5)$ & $4.8 \pm 0.7$ \\
\hline $\mathbf{E}$ & Saline + FSH & 4 & $15.6 \pm 0.5$ & - & 0 & - & $3.0 \pm 1.5$ \\
\hline $\mathbf{F}$ & PGF- $2 \alpha+$ FSH $\dagger$ & 4 & $15.5 \pm 0.3$ & $24 \cdot 3 \pm 2 \cdot 2$ & 3 & $1.159 \pm 0.086(7)$ & $4.8 \pm 0.6$ \\
\hline
\end{tabular}

* Vaginal perforation had not recurred up to Day 32 when the animals were killed.

$\dagger$ The animals were killed on Day 3 of the cycle after the treatment cycle. 
Table 3. Occurrence of large antral follicles $(\geqslant 0.8 \mathrm{~mm}$ diameter) in hysterectomized (Day 9) guinea-pigs and those treated with saline $(9 \mathrm{~g} \mathrm{NaCl} / \mathrm{l})$ or PGF-2 $\alpha$ (from Day 13) and pituitary homogenate or gonadotrophin (Day 16)

\begin{tabular}{|c|c|c|c|c|c|c|}
\hline \multirow[b]{2}{*}{ Group } & \multirow[b]{2}{*}{$\begin{array}{l}\text { Treatment after } \\
\text { hysterectomy }\end{array}$} & \multirow[b]{2}{*}{$\begin{array}{l}\text { No. of } \\
\text { animals }\end{array}$} & \multicolumn{2}{|r|}{ Healthy } & \multicolumn{2}{|r|}{ Atretic } \\
\hline & & & $\begin{array}{l}\text { No. of } \\
\text { animals }\end{array}$ & $\begin{array}{l}\text { Diam. } \\
(\mathrm{mm})\end{array}$ & $\begin{array}{l}\text { No. of } \\
\text { animals }\end{array}$ & $\begin{array}{l}\text { Diam. } \\
(\mathrm{mm})\end{array}$ \\
\hline A & $\begin{array}{l}\text { Saline + pituitary } \\
\text { homogenate }\end{array}$ & 4 & 3 & $0.875 \pm 0.016(15)$ & 4 & $0.876 \pm 0.017(19)$ \\
\hline B & $\begin{array}{l}\text { PGF- } 2 \alpha+\text { pituitary } \\
\text { homogenate }\end{array}$ & 6 & 3 & $0.875 \pm 0.020(13)$ & 5 & $0.857 \pm 0.008$ \\
\hline $\mathrm{C}$ & Saline $+\mathrm{hCG}$ & 4 & 4 & $0.848+0.013(9)$ & 3 & $0.895 \pm 0.034(7)$ \\
\hline D & PGF- $2 \alpha+$ hCG $\dagger$ & 6 & 4 & $0.866 \pm 0.016(17)$ & 4 & $0.859 \pm 0.011(21)$ \\
\hline $\mathrm{E}$ & Saline + FSH ${ }^{*}$ & 4 & 4 & $1.015 \pm 0.079(7)$ & 3 & $1.013 \pm 0.073(7)$ \\
\hline $\mathrm{F}$ & PGF- $2 \alpha+$ FSH $\dagger$ & 4 & 1 & $0.844(1)$ & 1 & $0.932 \pm 0.045(3)$ \\
\hline
\end{tabular}

* In these groups vaginal perforation had not recurred up to Day 32 when the animals were killed.

$\dagger$ The animals in these groups were killed on Day 3 of the cycle after the treatment cycle.

$\mathrm{C}$ and $\mathrm{E}$ was lower than those in Groups D and F, the difference was not significant in each case. When PGF-2 $\alpha$ was given simultaneously with gonadotrophins $50 \%$ of the guinea-pigs in Groups $B, D$ and $F$ ovulated and fresh, healthy-looking CL of ovulation were observed (Table 2). Luteinized follicles with entrapped ova, comparable in size with $\mathrm{CL}$ of ovulation were also commonplace. Vaginal oestrus recurred in every case and the mean cycle length of the 5 ovulating animals from Groups B and D was $18.8 \pm 0.6$ days, significantly shorter $(t$ test) than the $20.8 \pm 0.5$ days for Group $D$ in Exp. 1 (Table 1). However, gonadotrophin administration in addition to PGF-2 $\alpha$ treatment did not restore the cycle length to control values of 15-16 days. The animals in Group $F$ had the longest treatment cycle, lasting up to 30 days. Numerous antral follicles $>0.8 \mathrm{~mm}$ diameter were found in virtually every animal (Table 3 ). However, only 4 follicles, all atretic, with a diameter of $>1 \mathrm{~mm}(1.021-1.096 \mathrm{~mm}$ ) were found (one in each of Groups A, B, C and F). Group E animals had 2 healthy and 3 atretic follicles that ranged from 1.058 to $1.462 \mathrm{~mm}$ diameter. The wide spread luteinization usually associated with administration of gonadotrophin (Reed \& Hounslow, 1971) was not observed.

\section{Experiment 3: effects of hysterectomy and indomethacin on follicular development}

The diameters of all antral follicles $\geqslant 0.8 \mathrm{~mm}$ were measured and recorded (Table 4). Only 2 antral follicles, 1 healthy and 1 atretic, with a diameter $>1 \mathrm{~mm}$ (both $1.021 \mathrm{~mm}$ ) were found in Group C.

Table 4. Occurrence of large antral follicles $(\geqslant 0.8 \mathrm{~mm}$ diameter) in guinea-pigs hysterectomized (Day 9) and treated daily with indomethacin (from Day 9)

\begin{tabular}{|c|c|c|c|c|c|c|}
\hline \multirow[b]{3}{*}{ Group } & \multirow[b]{3}{*}{$\begin{array}{l}\text { No. of } \\
\text { animals }\end{array}$} & \multirow[b]{3}{*}{ Day killed } & \multicolumn{4}{|c|}{ Large antral follicles } \\
\hline & & & \multicolumn{2}{|r|}{ Healthy } & \multicolumn{2}{|r|}{ Atretic } \\
\hline & & & $\begin{array}{l}\text { No. of } \\
\text { animals }\end{array}$ & Diam. (mm) & $\begin{array}{c}\text { No. of } \\
\text { animals }\end{array}$ & Diam. (mm) \\
\hline A & 3 & 12 & 0 & - & 2 & $0.827 \pm 0.011$ \\
\hline B & 3 & 14 & 3 & $0.892 \pm 0.028$ & 2 & $0.882 \pm 0.025$ \\
\hline $\mathrm{C}$ & 3 & $18-20$ & 3 & $0.890 \pm 0.034(5)$ & 1 & $0.846 \pm 0.006(7)$ \\
\hline
\end{tabular}




\section{Discussion}

In Exps 1 and 2 the extension of the treatment cycle beyond the normal 15-16 days was probably because ovulation was delayed and not because ovulation occurred among more recently recruited follicles. This is because if PGF- $2 \alpha$ is involved in follicular development the critical period is likely to be Day 11 , the day when PGF- $2 \alpha$ concentrations in utero-ovarian blood begin to rise (Blatchley et al., 1972). Therefore, there should be no PGF-2 $\alpha$ deficiency of physiological significance and ovulation should not occur from a new population of follicles in Groups B and C of Exp. 1. Consequently, delayed ovulation must be the reason for the extension of the treatment cycle in these 2 groups, and the probable reason for the same extension in Groups D, E and F. The extension of the treatment cycle in Group F made it unlikely that the delay was due to deficiency in the amount of PGF-2 $\alpha$ used. No dose-response relation was observed between Groups $\mathrm{C}$ and $\mathrm{F}$. If the original batch of antral follicles had not ovulated but become atretic after 11-15 days of growth, then large atretic follicles of $\geqslant 0.8 \mathrm{~mm}$ diameter (Myers, Young \& Dempsey, 1936) would have been present in the ovary, but none was observed in 26 animals in Groups B-F in Exp. 1 and the 7 animals killed 1-2 days before the expected time of ovulation. Atretic follicles should be visible in the ovary for at least 6 days since the follicles stimulated into further growth by gonadotrophin injections on Day 16 in Groups B and D of Exp. 2 lasted until Day 3 of the following cycle (Table 3). Although treatment cycle lengths of Groups B-E and $\mathrm{H}-\mathrm{J}$ were not significantly different, there is a trend that, as PGF-2 $\alpha$ treatment was deferred, the cycle was lengthened and ovulation was further and further delayed. The developing follicles appeared to need exposure to PGF- $2 \alpha$ for a certain fixed period before they were capable of ovulation. The prolonged PGF- $2 \alpha$ treatment was required not only for induction of the preovulatory LH surge, but also for direct action of PGF-2 $\alpha$ on follicular growth. To elicit an LH peak in blood PGF- $2 \alpha$ took 10 min when given intravenously to rats (Sato et al., 1974) and 1-3 days when administered intramuscularly to ewes (Bono, Gaiani \& Seren, 1980).

The results from Exps 1 and 2 are difficult to reconcile with the idea that in guinea-pigs 2 populations of follicles become mature one after the other within one oestrous cycle (Bland, 1980): those of the first wave reaching maximal size $(0.8-0.9 \mathrm{~mm}$ diam.) on Day 10 and then regressing, while those of the other wave mature to the same size on Days 14-15. Injections of PGF- $2 \alpha$ between Days 9 and 15 would have been inducing ovulation from two waves of maturing follicles and therefore 2 distinctly different treatment cycle lengths should have been observed. Yet this was not confirmed by our observations (Table 1). The results in Table 1 also show that a much longer PGF-2 $\alpha$ treatment period was required to induce ovulation in hysterectomized guinea-pigs than in animals in which PGF- $2 \alpha$ synthesis was suppressed by indomethacin. There are 3 possible explanations. (1) Indomethacin, even used in sufficient amount to suspend ovulation in these experiments (Group G, Table 1) and in 4 times the dose considered to be sufficient in rats (Orczyk \& Behrman, 1972), was not as efficient as hysterectomy in reducing the amount of PGF-2 $\alpha$ reaching the ovary. (2) The surgical stress of hysterectomy delayed the cycle, but there was no relation between recovery and treatment cycle length. (3) The autonomic nerve endings in the uterus and ovary (all of which are derived from the ovarian plexus: Curtis, Anson, Ashley \& Jones, 1942) could relay the stimulus of rising PGF- $2 \alpha$ concentrations to the pituitary via the central nervous system. Hysterectomy obviously impaired the pathway of this feedback mechanism.

The results in Exp. 3 strongly suggest that both gonadotrophin and PGF-2 $\alpha$ are needed for follicular development and ovulation in guinea-pigs. Perhaps gonadotrophin administration alone restored ovulation to a very small proportion of the hysterectomized guinea-pigs in Groups $\mathrm{A}, \mathrm{C}$ and $\mathrm{E}$ (Table 2). Administered in conjunction with PGF-2 $\alpha$, gonadotrophins in amounts known to cause $100 \%$ ovulation in intact guinea-pigs (pituitary homogenate: Reed \& Hounslow, 1971; hCG: Rawson, Galey, Weinberg \& Hodgson, 1979) significantly shortened the cycle 
length and therefore PGF-2 $\alpha$ requirement from 21 (Group D, Table 1) to 19 days (the ovulating animals in Groups B and D, Table 2). However, the treatment cycle length was still longer than the control cycle value of $15-16$ days, and only about $42 \%$ of the animals ovulated. The numerous large $(\geqslant 0.8 \mathrm{~mm}$ diam.) antral follicles found in Groups B, D and F (Table 2) were obviously stimulated to grow to this size as a result of the gonadotrophin injection on Day 16 , as in normal guinea-pigs Day 3 was marked only by the presence of much smaller follicles (Bland, 1980) usually not larger than $0.6 \mathrm{~mm}$ (W. H. Tam, unpublished observations). Yet, these antral follicles in the absence of PGF-2 $\alpha$ remained the same size approximately 10 days later in Groups $A, C$ and $E$. In guinea-pigs mean follicular diameter increases from about 0.8 to $1.0 \mathrm{~mm}$ between Days 11 and 16 and then, within the last few hours, during the preovulatory LH surge (Croix \& Franchimont, 1975), grows to $1.2 \mathrm{~mm}$ diameter (Myers et al., 1936). When PGF-2a was suppressed by hysterectomy and simultaneous daily injection of indomethacin (Exp. 3), only 2 antral follicles of $1 \mathrm{~mm}$ diameter were found in 9 animals, 3 of which had passed the normal time of ovulation. It may be that PGF-2 $\alpha$ is required on Days 11-16 to stimulate the development of follicles from 0.8 to $1.0 \mathrm{~mm}$ diameter in preparation for the final rapid preovulatory growth occurring hours before ovulation.

This work was supported by a grant (A6792) awarded to W.H.T. by the Natural Sciences and Engineering Research Council of Canada. R.J.J.R. was a recipient of an Ontario Graduate Scholarship during part of this study. Most of the PGF- $2 \alpha$ used in this work was a generous gift of Dr John Pike, Upjohn Company, Kalamazoo.

\section{References}

Bland, K.P. (1980) Biphasic follicular growth in the guinea-pig oestrous cycle. J. Reprod. Fert. 60, 73-76.

Blatchley, F.R., Donovan, B.T., Horton, E.M. \& Poyser, N.L. (1972) The release of prostaglandins and progestins into the utero-ovarian venous blood of guinea-pigs during the oestrous cycle and following oestrogen treatment. J. Physiol., Lond. 223, 69-88.

Bono, G., Gaiani, R. \& Seren, E. (1980) Prostaglandin $\mathrm{F}-2 \alpha$ and LH release in immature ewes. $J$. Reprod. Fert. 59, 1-4.

Croix, D. \& Franchimont, P. (1975) Changes in the serum levels of the gonadotropins, progesterone and estradiol during the estrous cycle of the guinea-pig. Neuroendocrinology 19, 1-11.

Curtis, A.H., Anson, B.J., Ashley, F.L. \& Jones, T. (1942) The anatomy of the pelvic autonomic nerves in relation to gynecology. Surgery, Gynec. Obstet. $75,743-750$.

Lau, I.F., Saksena, S.K. \& Chang, M.C. (1974) Prostaglandins F and ovulation in mice. J. Reprod. Fert. 40, 467-469.

Myers, H.I., Young, W.C. \& Dempsey, E.W. (1936) Graafian follicle development throughout the reproductive cycle in the guinea-pig with especial reference to changes during oestrus (sexual receptivity). Anat. Rec. 65, 381-401.

Orczyk, G.P. \& Behrman, H.R. (1972) Ovulation blockade by aspirin or indomethacin-in vitro evidence for a role of prostaglandin in gonadotrophin secretion. Prostaglandins 1, 3-20.

Rawson, J.M.R., Galey, C.I., Weinberg, L.C. \& Hodgson, B.J. (1979) Effects of gonadotropins on follicular development, ovulation and atresia in the mature guinea-pig. Horm. Res. 10, 25-36.
Reed, M. \& Hounslow, W.F. (1971) Induction of ovulation in the guinea-pig. J. Endocr. 49, 203-211.

Sato, T., Taya, K., Jyujyo, T., Hirono, M. \& Igarashi, M. (1974) The stimulatory effect of prostaglandins on luteinizing hormone release. Am. J. Obstet. Gynec. 118, 875-876.

Strickland, S. \& Beers, W.H. (1979) Studies of the enzymatic basis and hormonal control of ovulation. In Ovarian Follicular Development and Function, pp. 143-153. Eds A. R. Midgley \& W. A. Sadler. Raven Press, New York.

Tam, W.H., Beveridge, W.K. \& Tso, E.C.-F. (1982) Effects of gonadotrophins, hypophysectomy and prostaglandin F-2 $\alpha$ on corpora lutea and ovarian follicles, and evidence for the presence of PGF- $2 \alpha$ receptors in the ovarian follicles and interstitium of non-pregnant guinea-pigs. J. Reprod. Fert. 64, 9-17.

Thorburn, G.D., Cox, R.I., Currie, W.B., Restall, B.J. \& Schneider, W. (1973) Prostaglandin F and progesterone concentrations in the utero-ovarian venous plasma of the ewe during the oestrous cycle and early pregnancy. J. Reprod. Fert., Suppl. 18, 151-158.

Tsafriri, A., Lindner, H.R., Zor, U. \& Lamprecht, S.A. (1972a) In-vitro induction of meiotic division in follicle-enclosed rat oocytes by LH, cyclic AMP and prostaglandin $\mathrm{E}_{2}$. J. Reprod. Fert. 31, 39-50.

Tsafriri, A., Lindner, H.R., Zor, U. \& Lamprecht, S.A. (1972b) Physiological role of prostaglandins in the induction of ovulation. Prostaglandins 2, 1-10.

Tso, E.C.-F. \& Tam, W.H. (1977) The effect of continuous treatment with prostaglandin F-2 $\alpha$ on oestrous cycle length and corpus luteum regression in hysterectomized guinea-pigs. J. Reprod. Fert. 50, 335-336. 